\title{
The changing meaning of Taylagan Festival for contemporary Russia Buryat society: An adaptation of tradition
}

\author{
Rania Ayu Shila Febriani Adari ${ }^{1 *}$, Mina Elfira ${ }^{2}$ \\ 1,2 Department of Russian Studies, Universitas Indonesia, Indonesia \\ *Corresponding author \\ E-mail address: raniaayusfa@gmail.com \\ DOI: https://doi.org/10.21107/sml.v4i2.10527
}

\begin{tabular}{|c|c|}
\hline Article Info & Abstract \\
\hline $\begin{array}{l}\text { Keywords: } \\
\text { Buryat } \\
\text { Invention of } \\
\text { tradition } \\
\text { Neo-Shaman } \\
\text { Russia } \\
\text { Taylagan Festival }\end{array}$ & $\begin{array}{l}\text { Festival is a product of a culture that develops according to the needs } \\
\text { and times, including the Taylagan Festival. Taylagan Festival is one of } \\
\text { the most important annual rituals for the Russian Buryat Shamans. In the } \\
\text { contemporary era, this festival has also been performed for tourists. By using } \\
\text { Roland Barthes's semiotic theory, this research explores the impact of the } \\
\text { changes of Taylagan Festival meanings for Russian Buryat contemporary } \\
\text { society. At the same time, Eric Hobsbawm's "The Invention of Tradition" } \\
\text { (1992) is used to investigate the inventory of Taylagan Festival traditions, } \\
\text { based on qualitative data collected through intensive interviews for selected } \\
\text { informants. By using the descriptive analysis method, the research result } \\
\text { shows that the change in the sacred values of the Russian Buryat Shamans in } \\
\text { the Taylagan Festival has been started since the presence of Neo-shamans as } \\
\text { a form of cultural adaptation during the Contemporary Era, which is known } \\
\text { to be more modern and active in social and cultural activities. }\end{array}$ \\
\hline
\end{tabular}

Citation suggestion:

Adari, R. A. S. F., \& Elfira, M. (2021). The changing meaning of Taylagan Festival for contemporary Russia Buryat society: An adaptation of tradition. Simulacra, 4(2), 131-144. https://doi.org/10.21107/sml.v4i2.10527

Received 29 April 2021; Received in revised form 30 August 2021; Received in the second revised form 10 October 2021; Accepted 11 October 2021; Published online 25 November 2021. 


\section{Introduction}

Russia is known as the largest country in the world based on the official book of the "Russian Federation State Statistics Service Agency" or "Федеральная Служба Государственной Статистики" in 2016. Moreover, "Россия и Cтраны Mира" ("Russia and the Countries of the World") states that Russia has an area of about 17,125,000 km2 and there are approximately 146,400,000 inhabitants in 2014. With this area size, it is undeniable that various ethnicities inhabit Russia. It can be argued that its ethnic diversity is caused by the fact that Russia is flanked by two continents, each of which has its own different strong culture, Asian and European. The Russian Federation of State Statistics Service Agency in 2012 also added that the most dominant population occupying Russia is ethnic Russian with 41\% Orthodox Christians. There are also people of Asia descent, such as Bashkir, and Chechen who are Muslim.

In addition, Russian society is also familiar with animism, dynamism, and paganism. These ancient Russian beliefs remain even after Orthodox Christianity and modernisation. In fact, a cultural mix of paganism and Orthodox Christianity can be seen from the depiction of the horse St. Flor and St. Lavr (Святой Флор и Святой Лавр) in a popular ceremony of the Russian Orthodox Church. An ancient pair of divine twins replaced the ceremony by this pair of saints in the traditions of ancient Slavic society (Ivanov, 2008: 116). Russia still embraces paganism today can also be seen from the practice of shamanism and the high attractiveness of tourists and residents to Russian shamans (Shevchenko, 2019). Paganism tends to give Russian society a meaning that can protect themselves from strangers. So, paganism is considered the best religion for Russian society (Istarkhov, in Mitrofanova, 2016: 222).
The Buryat is an ethnic group in SiberiaRussia that still embraces shamanism. Mircea Eliade, a Romanian historian and philosopher, revealed that shamanism is a religious phenomenon in Siberia and Central Asia that originated from the Tungusic Shaman (1964: 4). This belief of shamans, which has still existed in contemporary Russian society, mainly in Siberia, has a long history. It is argued that the influence of shamanism had been brought directly by the Mongols from Mongolia. According to Harold Williams, a Russian and Soviet philologist and commentator from New Zealand, the leader of the Mongols through the Tartar army tried to conquer Russia in ancient times. Russia and China then were dominated by wandering chieftains who also ruled south of Lake Baikal. Mongols called them the Buryats. Later they came under Russian rule when the Russian Tsar expanded their empire in Eastern Siberia. Another Mongolian ethnic group, Kalmyk, fled the conflict to Dzungaria and started to settle on the steppe of the Southern Volga in the seventeenth century. Around two million Mongols settled in the region between Manchuria and Altai (Zohrab, 1987: 179).

The Buryats have continued their tradition by practising their belief rituals. A ritual is usually held for life matters to strengthen social and cultural relations, which refers to festivals that are more easily recognised by the public. It proves that human life is attached to ritual. In other words, the rituals are part of the festival. Usually, ritual activities are carried out to help people understand the interrelationship between rituals, nature, individuals and groups (Etikpah, 2015: 349). This illustrates that any activity carried out by a person or group will affect society, except the Buryat shamans in Russia. The Russian Buryats have strong customs with their shamanic beliefs. However, the implementation of 
customs such as that of the shamans is also influenced by the policies of the Russian Government. For example, at the beginning of the Soviet Union Era, all religious activities were prohibited. However, at the end of the Soviet Union Era, a new concept of openness, known as Перестройка /Perestroyka/, was launched by Gorbachev's Government. This concept allowed Soviet people to organise religious events again (Mitrofanova, 2016: 105-106). The era of openness also impacted this shamanism practice, as its believers were allowed to perform their various rituals. The revival of shamanism practised in Russia reached its peak in 1993 when the Buryat shamans began to do their rituals again, called Taylagan (Zhukovskaya \& Humphrey, 2000: 28).

Taylagan is one of the spiritualuniqueness of the Russian Buryat shaman that still exists today. However, culture is not static and even often changes by the times, as stated by Eric Hobsbawm in his book, The Invention of Tradition (1992), regarding the discovery of culture. According to Hobsbawm, there is a combination of elements of life and a new culture in a particular culture. It can be seen from Shamanism practice. Shamanism attracts researchers because of the unique traditions shared by the Buryat shamans in Siberia, Russia. There has been some research about Russian Buryat shamans, mainly the Taylagan Festival, performing Shamanism rituals. However, there is no research focusing on changing the meaning of the Taylagan Festival by the Buryat shaman in the Contemporary Era. Thus, this study aims to identify the changes in meaning at the Taylagan Festival for the Russian Buryat community in the Contemporary Era. Aside from being a worship duty for the Buryat Shamans, the Taylagan Festival can be a place for performances for tourists that positively impact residents in many sectors, such as economic, social, and cultural.

\section{Method}

This research used a descriptive analysis method. According to Creswell (2007), descriptive-analytical research is a method for exploring and understanding meaning by some individuals or groups of people ascribed to social or humanitarian problems. This qualitative research process involves essential efforts, such as asking questions, collecting specific data, analysing data productively, and interpreting the meaning of the data (Creswell, 2007). Meanwhile, descriptive research (Hardani, Andriani, et al., 2020:54) is directed to provide symptoms, facts, or events systematically and accurately regarding the characteristics of a particular population or area.

In addition, this research also used a literature study to complete the data. This literature study is carried out by collecting and processing research data sourced from Russian books, articles, journals, news programs, and social media related to the values, norms and culture that develop in the social situations studied (Sugiyono, 2009: 291). Researchers also used some videos as data sources to see the real story of the Taylagan Festival.

Furthermore, this research method also used an interview technique to support explanations from some videos and add direct understanding from the Russian community regarding the Russian Buryat shaman and the Taylagan Festival. This interview was conducted on fifteen informants, including Shamans and participants who had never participated in the Taylagan Festival. The researcher chose the informants based on the differences in age, profession, and city of residence. This technique is implemented by collecting data through interviews via the internet and a Russian social media, called Vkontakte. The interviews were conducted in the Russian language and were translated into English by the researchers themselves. 
The informant's identities are disguised to maintain research ethics. The interviews were conducted with several Russian communityinformants to directlyunderstand the Russian community about the Russian Buryat shaman and the Taylagan Festival. Therefore, the informants were obtained using the snowball system, taking samples through a known network. Thus, the profile information of the informants is guaranteed valid. The informants interviewed came from various cities in Russia, such as Moscow, Saint Petersburg, Bryansk, Chechen Republic, Krasnoyarsk. They also have different beliefs, including Orthodox Christianity, Islam, Buddhism, Hinduism, and Shamanism. In this way, this research got many opinions and understandings of Russian society from various backgrounds, including differences in religion, city of residence, age, and profession. So, there were several steps to complete this research, such as collecting information related to the Russian Buryat shaman, including history, developments, and customs. At the same time, interviews were conducted with several informants. Furthermore, by using the theory of semiotic by Roland Barthes and the theory of tradition discovery by Eric Hobsbawm, these data are processed and determined concerning changes in the meaning of Taylagan.

First, the data was processed by sorting out brief biodata of the informants, then learned all the answers from the interviews. Through the informants' answers, the researcher was able to find out more information about their personal views on the Festival Taylagan and Shaman in Russia, which was investigated more deeply with Roland Barthes's semiotic theory. Signs have many interpretations of meaning and even multiple meanings depending on the interpreter itself. Behind the special festival, some instruments are used to complement the event. Therefore, the researcher reveals the special meaning of the Taylagan festival instrument. The relationship between signifier and signified is very important in semiotic theory. At the Taylagan festival, the instruments are considered to be a sign peeled off its meaning. For example, the colourful ribbons (signs) that Buryat shamans use to tie birch trees have a principle of harmonious living. After that, the researcher found several changes to the Festival Taylagan and shaman in Russia since its appearance until now. It appears something new with the discovery of culture and explored with the theory of The Invention of Tradition by Eric Hobsbawm. Therefore, Festival Taylagan has changes in meaning that can lead to new cultural discoveries influenced by several factors, such as economic, social, and cultural.

\section{Results and Discussion}

This section is divided into two parts. First, it starts by explaining the history of the development of Buryat shamans and the Taylagan Festival, which has a very long journey. From generation to generation, Buryats have always tried to maintain their culture. That is why due to the consistency and efforts of the Buryat ancestors, today's cultural traditions are still routinely carried out. One of the cultural traditions that are carried out is the Taylagan Festival. The Taylagan Festival is proof of the cultural tradition held every year to honour the spirits of their ancestors.

Second, this part discusses several changes in meaning at the Taylagan Festival in the Contemporary Era, influenced by external and internal factors. This part is essential to understand why cultural traditions will not always be the same as they were first discovered. 


\section{Buryat Shaman and the Taylagan Festival then and now}

Siberian culture is often associated with mystical or even unique ancient Siberian religions, such as the combination of folk superstition, shamanism, spiritualism, and Orthodox Christianity with touches and influences from various cultures, nations, and places (Siembieda, 1998). Besides, Russia's belief in evil spirits, demonic, witches, and the supernatural remains strong and primarily unchanged from the 19th to the 20th centuries (Siembieda, 1998: 9).

Moreover, in the 21st century, the belief in the supernatural is still firm, especially in the Siberian region (Russia Beyond, 2019). In his book "Trajectories of Mysticism in Theory and Literature", Philip Leonard stated that the elements of mysticism could be traced through various religious traditions and linked to various events, experiences, forms of behaviour, and ways of expression. Some religious traditions with an emphasis on mysticism include Buddhism, Taoism, and Shamanism. It is argued that shamanism rituals and symbols are part of the Siberian people cultural identity. Cultural identity is the feeling of belonging to a national group that is part of an individual's self-image based on experiences of cultural "similarity" (Gudaite, 2015: 119). The diversity of Siberian mythology proves the spiritual richness of Siberian itself. It can be found through the Shamanism of the Russian Buryat, which is why Shamanism in Siberia is common today.

The evolution of shamanism in Russia has had its ups and downs, from the Tsar era, the Soviet Union era, to the Federation era. Zhukovskaya \& Humphrey stated that shamanism in Russia appeared from 1920 to the end of 1980. However, shamanism experienced a setback during the Soviet Union era, primarily prohibiting religion (2000: 26). Furthermore, Fahrurodji explained (2005: 111) that the background of religious ideology was the basis for the Russian Government's policy to be replaced by the ideology of communism. It also had an impact on shamanism in Siberia. The Soviet Union's policy prohibiting all religions from holding religious events forced shamans in Siberia to abandon any ceremony or ritual.

As previously mentioned, at the end of Communism, Gorbachev's Government launched policies known as Perestroika (restructuration) and glasnost' (openness). One of the impacts of these new policies is that they re-allowed Soviet people to practice their religious activities, for example, shamanism rituals (2005: 173). The implementation of these new policies on religion was delivered to a new generation of shamans. Because of these new policies, the Russian people carried out their spiritual activities again. Shamans in Siberia were also involved in the same way, for example, the shamans from the Buryat tribe. It can be said that the rise in popularity of the Buryat shamans in Siberia experienced its peak at the end of the Soviet Union, which continued until the Federation Era in 1991. One of the spiritual activities that Buryat shamans have held until now is the Taylagan Festival.

Taylagan is one of the most important rituals for Buryat shamans to honour their ancestors. There are also other essential factors of the Taylagan ritual described by one of the informants, who is a famous Buryat shaman, Valentin Khagdaev, through the interview:

Тайлаган - это есть молебствие с жертвоприношениями. Бывают они семейные (несколько семей), родовые, межродовые и племенные или общенародные

Taylagan is a prayer of sacrifice attended by families (several families) such as children 
and grandchildren, intergenerational and inter-ethnic, or public (interview with Khagdaev via Vkontakte, 2020).

Based on Khagdaev's statement, it can be said that the Taylagan festival is considered a sacred ceremony for the Buryat shamans. The ceremony has several stages of sacrifice, including animal slaughter and recitation of prayers for offerings of local spirits, which is why the Taylagan festival has appeared to be a spiritual activity and a family gathering event for the Buryat shamans. Taylagan Festival was also held to honour the spirits of Olkhon Island, Mount Baragkhan in Barguzin, the spirits of Bulagat Buryat ancestors, Bukha Noyon. All of them are also considered as protectors of the entire Buryat tribe. (Zhukovskaya, 2000: 28). Meanwhile, in the contemporary era, many Russian have witnessed several events held by shamans in Siberia. It is proven by the results of interviews with several respondents who said that they had participated in the rituals of the Siberian shaman, including the Taylagan Festival.

The Russian's belief in myths or shamans can be seen from the results of the interviews.

Table 1. Explanation of the Result of the Interviews

\begin{tabular}{|c|l|c|}
\hline No & \multicolumn{1}{|c|}{ Results } & $\begin{array}{c}\text { Total of } \\
\text { informants }\end{array}$ \\
\hline 1. & Knowing about Shaman & 13 \\
\hline 2. & Believing in Shaman & 12 \\
\hline 3. & $\begin{array}{l}\text { Knowing about ritual or } \\
\text { festival }\end{array}$ & 13 \\
\hline 4. & Visiting shaman's ritual & 8 \\
\hline 5. & $\begin{array}{l}\text { Knowing about } \\
\text { Taylagan Festival }\end{array}$ & 5 \\
\hline 6. & $\begin{array}{l}\text { Visiting Taylagan } \\
\text { Festival }\end{array}$ & 2 \\
\hline
\end{tabular}

Based on the results of the interviews, the majority of informants knew about the Buryat shaman. Only two of fifteen informants said they did not know about shamans, including those from the Buryat Tribe in Russia. Some informants have a common knowledge of shamans. For example, informant number three $(\mathrm{Abu})$ said that shamanism could be found in the Urals and some places in Siberia. They have special abilities passed on from generation to generation.

Moreover, they live far away and often gather for ceremonies and rituals. Meanwhile, informant number eight (Acu) and eleven (Ada) said shamans are blessed with special abilities to communicate with spirits and heal people. Based on the various opinions of informants, it can be said that they are familiar with shamanism. Their belief in shamanism also supports this. It can be seen from eleven informants who claimed to believe in shamanism. One of the informants, the first informant (Aba), said they sometimes believed, while three other informants said they did not believe.

The informants also know about their everyday rituals. It is based on the fact that thirteen informants explained their knowledge of shaman rituals. Two informants said that the shaman performs rituals in the big field, near the fire, with a tambourine. They also say or murmur something to protect the village and all its inhabitants from the evil that lives in the forest when their ancestors' spirits enter the shaman's body. At that time, they could communicate through shamans with their descent. Other respondents also mentioned several shaman rituals such as opening the right path, fortune, healing and cleansing, and weather rituals.

Seven informants said they had visited a shamanic ritual, one of the informants said they had heard a shaman performing the ritual with the sound of a tambourine and a 


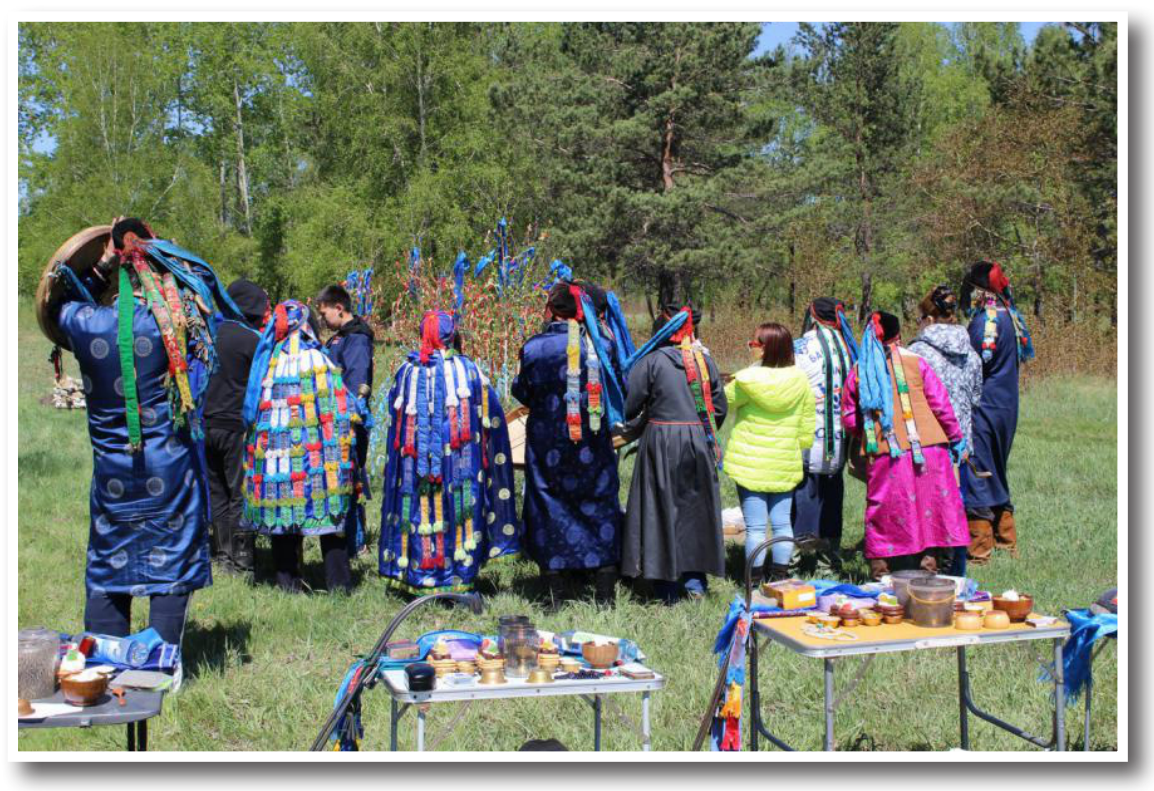

Picture 1. Buryat shamans gathering to perform a ritual

(Source: Sergey Shotnikov - through the interview)

burning fire on the Olkhon Island, and seven other informants claimed to have never visited a shamanic ritual at all. Meanwhile, only five out of fifteen informants knew about the Taylagan Festival. Informant seven had come to Taylagan and saying that this ritual was performed in Irkutsk in an open area in the middle of the forest. While they performed the ritual, they slaughtered a horse as a sacrifice. Then, they cooked and gave it to the Taylagan participants. Another informant, a shaman from Tuva, stated about his presence to Taylagan as a guest. He also added that shamans perform the ritual and enter a trance to communicate with the spirits of their ancestors as guardians of the great Baikal. Unfortunately, only two informants claimed to have witnessed Taylagan.

Nonetheless, those who do not know and have never been to Taylagan express their interest in Taylagan. They are also eager to witness and come to see it directly. However, some informants think that many shamans nowadays cheat for selfish purposes, as revealed by respondent four. Thus, these informants believed that rituals were sometimes performed only for show.
The picture above is a ritual performance by the Buryat shamans obtained from an interview with Sergey Shotnikov through Russian social media (Vkontakte). In the interview, Shotnikov explained that:

Этот обряд проводился в Иркутске в 2017 году, в особом месте в городе, где есть нетронутая природа площадью 150 га. Проводили шаманы общины “Байкал”. Как видите они уже с бубнами. в жертву никого не приносили, только продукты (водка, молоко, печенье, конфеты и т.п.)

This ceremony was held in Irkutsk in 2017, in a special place in the city, where there is untouched nature with an area of 150 hectares. The shamans of the "Baikal" community saw them off. It can be seen that they are already using tambourines. no one was sacrificed, only food (vodka, milk, cookies, sweets, etc.)

The Shaman Sergey Shotnikov explains the picture as below:

Это 2019 год особенный обряд, когда шаманы входят в особое состояние 


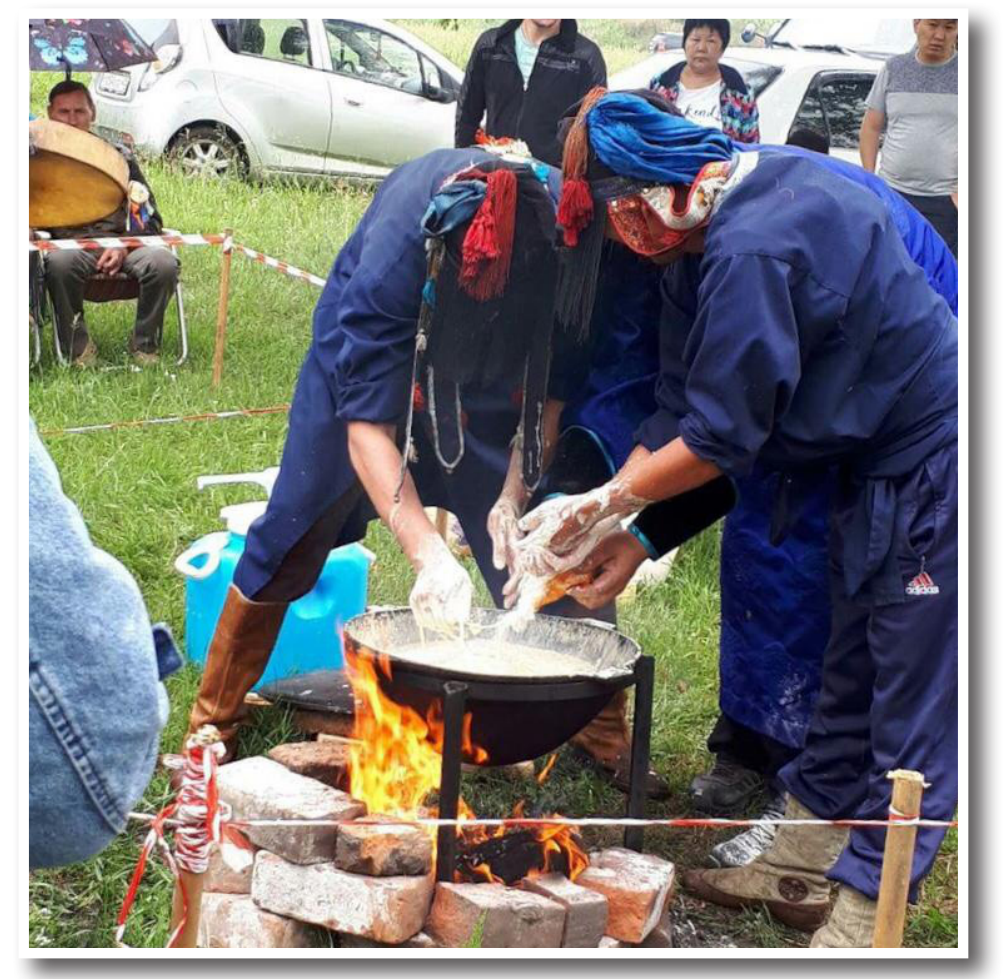

Picture 2. Two Buryat shamans cooking a special dish for their special ceremony (Source: Sergey Shotnikov - through the interview)

мешают кипящий саламат (блюдо из сметаны и муки) годыми руками.

It is a special ceremony in 2019 when shamans enter a particular state and interfere with boiling Salamat (a dish of sour cream and flour) with their bare hands.

Also, Nikolay Khromov, a Tuva shaman who was also a guest of the Taylagan Festival, said that this festival is held once a year on Olkhon Island, allowing anyone to come and see the ritual of the Buryat shaman for free. It is just that visitors need to know the exact date when it is held because the dates are different every year. According to Khromov, the Taylagan Festival is a special ritual for Buryat shamans, so that other shamans from the different tribes are not allowed to participate in this ritual, and people can only be guests. Even though he disagreed with this rule, Olkhon is part of their land, so it is their rule too (the Buryat shaman). Khromov also added that in the Taylagan Festival,
Buryat shamans perform rituals and enter the spirits of their ancestors, which are 12 Noyns and 12 shamans, in turn, can enter a trance the spirit of the guardian of the place will enter into it. 12 Noyn is the guardian spirit of Lake Baikal on the island of Olkhon, Siberia, Russia. However, the Taylagan festival has deep origins. The Buryat shamans in Russia have a very long history of getting to this point in this Contemporary Era.

\section{Meaning transformation of Taylagan Festival in the contemporary era}

A culture is assumed to be something ancient sometimes, even something relatively recent and invented. Eric Hobsbawm argues it in his book, "The Invention of Tradition" (1983), which focused on social, political and cultural conditions. According to Hobsbawm, inventing traditions are assumed to be a process of formalization and ritualization, characterized by the past (Hobsbawm 1983). In this case, The Invention of Tradition can 


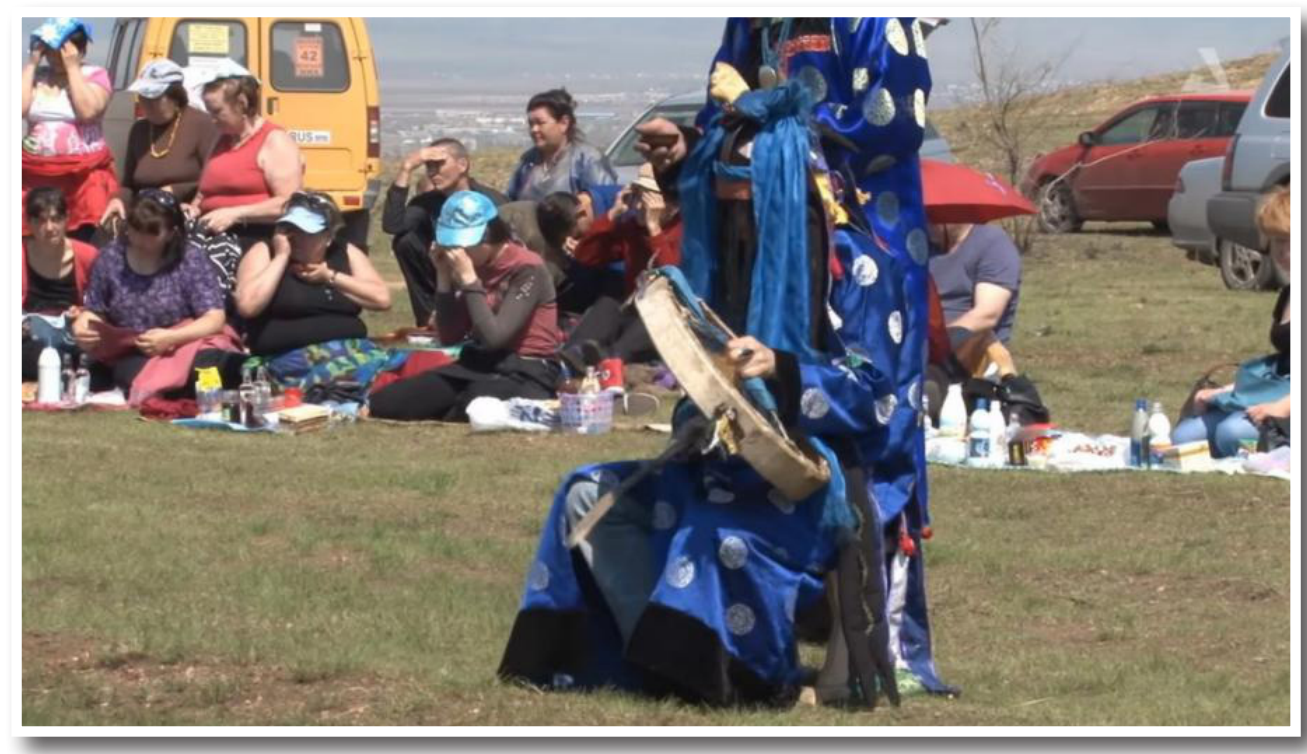

Picture 3. A Buryat Shaman is beating a tambourine

(Source:APEHA Телеканал,

https://www.youtube.com/watch?v=e1_YJQNxxf8Elist=LLEindex=10Et=6s)

be attached to Taylagan Festival since it is considered as one of the sacred rituals by the Buryat shaman. Moreover, this tradition was passed down by the ancestors of the Buryat to pray for the spirits of the Buryat ancestors as an honor. The Taylagan Festival still exists until now firmly.

It can be said that the existence of the Gorbachev new policies had given an impact in developing some modifications of shamanism ritual practices, particularly those from the Russian Buryat, in contemporary Russian society, even in the post-perestroika years. One of the things that stood out in Russia's Buryat shamanic society is Neo-Shamans. The Gorbachev new policies opened the way for shamans to call themselves a new generation of shamans with a contemporary thinking style. They call it "Neo-Shaman". Zhukovskaya (2000) stated that Neo-Shaman is a new generation of shamans with a modern perspective.

It can be seen from the way they spend their daily lives. Besides being a shaman, they are also professional workers in private and Government sectors. Moreover, besides actively participating in new shaman associations, they have contributed to some popular media events. They are also eager to express their belief in an academic environment. By doing that, they expect the world will more recognize their religious status. Neo-shaman people have several characteristics. For example, they obtained higher education than the previous shamans did. They are also younger than any other old generation with modern costumes and contemporary thinking styles. Therefore, they often participate in social and cultural activities and work in various public institutions such as universities and institutes, schools, libraries, or administrative officials (Zhukovskaya, 2000: 26).

The life of Valentin Khagdaev, a NeoShaman in Russia, is an example of it. Khagdaev is a humanist who studied humanities and graduated from the State Institute of Culture of East Siberia from the Buryat Republic. He is also a well-known shaman and once served as the Head of the Buryat Shaman in the Olkhon Island area, Irkutsk, Russia (AP Archive, 2017). As a former Head of Shaman, he participated in the first Taylagan ritual held in 1993. As a sacred 
ritual for Buryat shamans, this Taylagan was attended by many Buryat shamans and their families. However, Buryat shamans are not the only ones who can participate in the Taylagan Festival. Anyone can come to see the rituals, including shamans from other tribes and ordinary people who are not shamans.

In the interview, Khagdaev revealed that there were around 3,000 locals who visited the Taylagan Festival at that time. It is different today. In this contemporary era, many locals and foreign tourists are more enthusiastic about this event. They come to Siberia, Olkhon Island, to witness this annual event of the Buryat shaman. Every year, Khagdaev said that the number of tourists who come to visit Baikal Lake has increased. As most of them usually come by car, parking lots usually get packed during the event.

Picture 3 above shows the activity carried out by one of the Buryat shamans in the
Taylagan ritual that is also accompanied by crowds of visitors surrounding the shamans.

The enthusiasm of visitors can also be seen from the picture above and the explanation of Aleksandr Panfilov, a tour guide leader who organizes trips for foreign tourists visiting Baikal. Panfilov organizes expeditions to the South Olkhon region where there are many natural beauty environments, such as rocky hills and engaging local events, where they can see the performance of special spiritual powers, such as the Taylagan event (Panfilov, 2016). The crowds of visitors who come to enjoy the beauty of the island of Olkhon or witness the Taylagan Festival provide opportunities in the economic sector for local people. So, this event can also support the economy of the local community.

A German shaman, Petra Hans, who worked as a dental assistant, even participated in the Taylagan. Hans came to Siberia to take part in a shamanic initiation to communicate with nature and ancestors

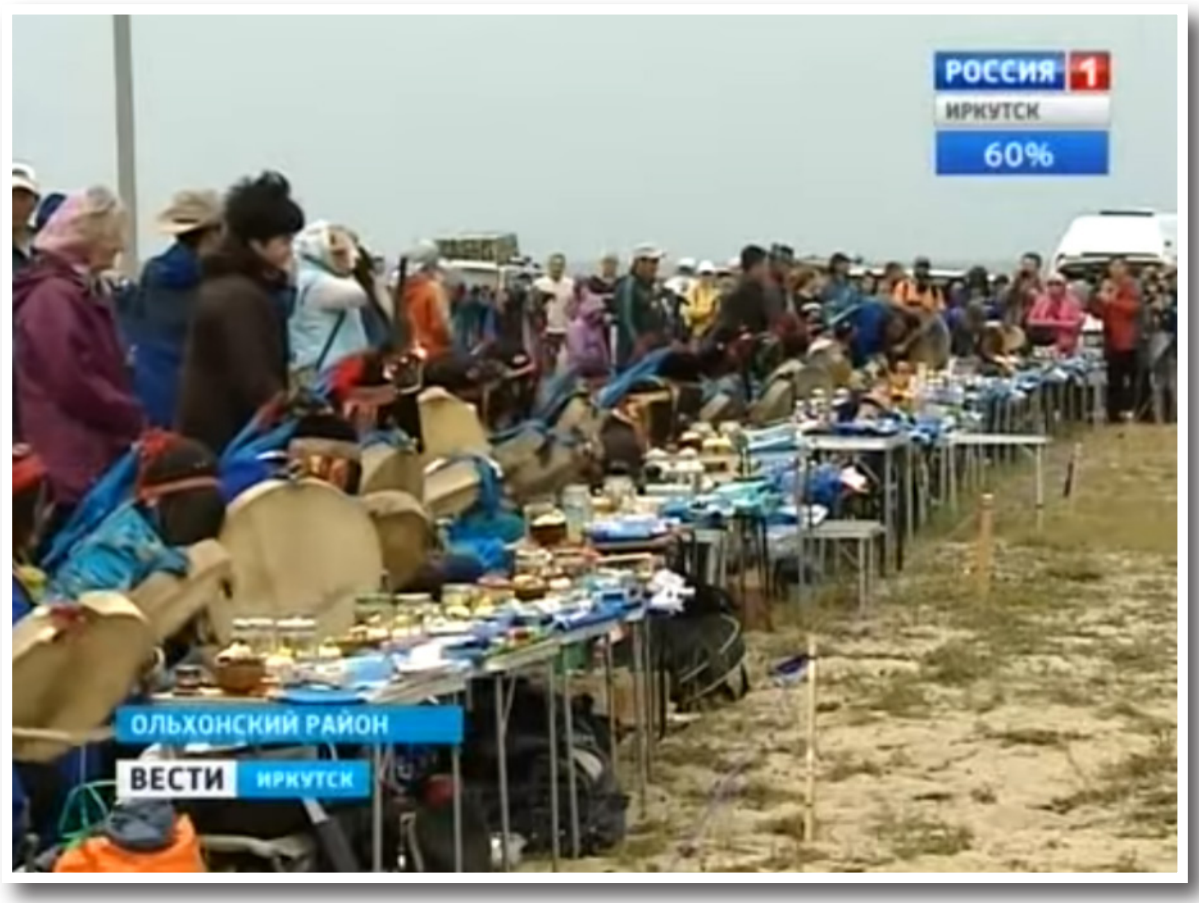

Picture 4. The activity of the Buryat shamans in Taylagan surrounded by tourists (Source: Vesti-Irkutsk, 2016, https://www.youtube.com/watch?v=fzafLsB48tUElist=LLEindex=3) 


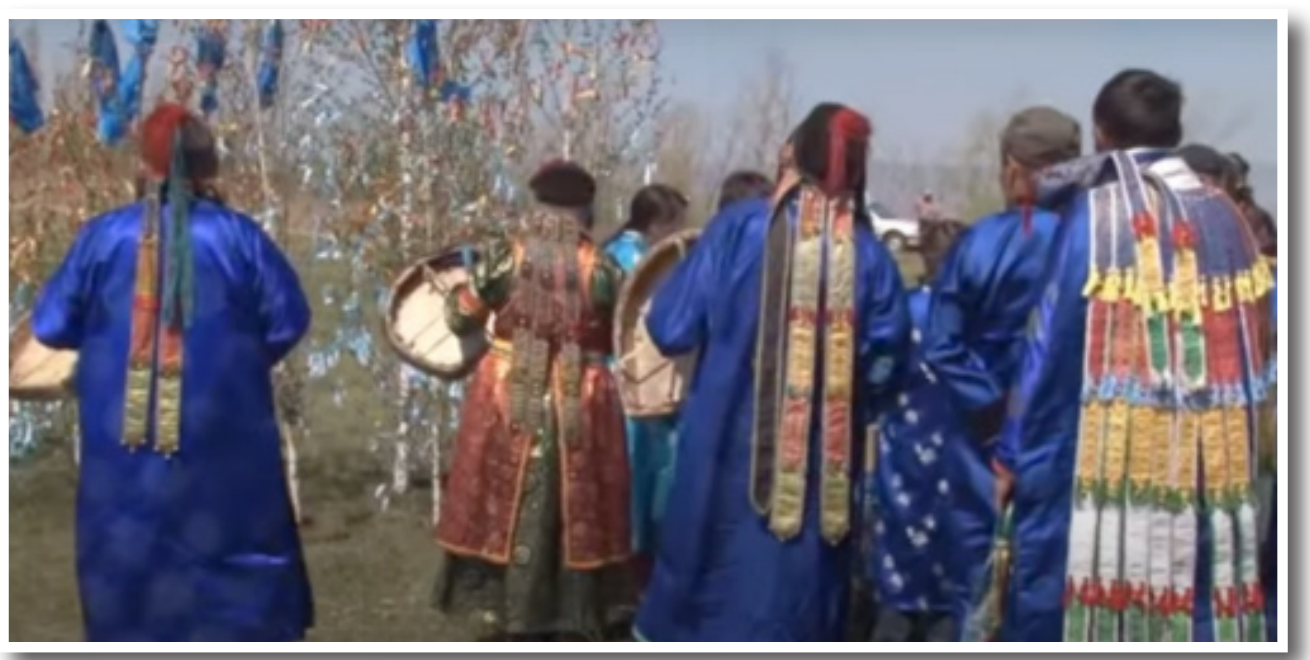

Picture 5. Buryat shamans hitting a tambourine in front of birch trees that tied up with colorful ribbons

(Source:APEHA Телеканал, https://www.youtube.com/watch?v=aauHakFFxxw\&list=LLEindex=8)

(Hans, 2016). In 2018, the founder of the modern art gallery, Viktor Bronshtein, participated in the Taylagan. Although he is an Orthodox Christian, Bronshtein admitted that shamanism is the strongest belief from an ancient culture that came from somewhere and has not changed in our times, and it is very interesting (Bronshtein, 2018). It appears that there is a difference between Taylagan in 1993 and Taylagan in the following years, such as 2016 and 2018. In 1993, Taylagan was only visited by the locals, as the Taylagan has been known to the public, and more visitors came to witness it. In addition, the symbolic meaning contained in the picture above is when the shaman is beating a tambourine. For the visitors, the rhythm that comes out of the tambourine may just be entertainment. However, it has a meaning, especially for the Buryat shamans, because they can reach out to the spirit and communicate with it (Li, 1992: 52).

The picture above performs the Buryat shamans are hitting a tambourine and placing colorful ribbons on a birch tree. The birch tree or береза /bereza/ is a tree highly respected by the Buryat shamans. This tree that represents sacred and holy has a special meaning which represents life in harmony with nature for the Buryat shamans. According to Khromov, a Shaman from Tuva, the birch tree is sacred, and the colored ornaments (ribbons) hung on it, a sacred symbol, is a mystery. These trees are energy conductors for the Buryat shaman. During the Taylagan ritual, the Buryat shaman walks in a circle, turning a spiral of energy so that the tree gets energy. As Valentin Khagdaev said during in his interview, that:

“Она (береза) символизирует связь со
всеми тремя Мирами. Как мировое
дерево кроной уходит в Верхние миры,
Срединным стволом в среднем мире,а
корни уходят в Нижние миры..”

"She (birch) symbolises the connection with all three Worlds. How the world tree with its crown goes to the Upper Worlds, the Middle trunk in the middle world, and the roots go to the Lower Worlds."

Based on the explanation above, it can be seen that the birch tree in the Taylagan ritual is useful to symbolize the relationship with the three worlds. The world tree goes with its crown to the upper world, the middle trunk 
in the middle world, and its roots going to the underworld. In the picture above, there are also colorful ribbons tied up to the birch trees. This colourful ribbon or zalaa is one of the instruments in this festival. Wieruczka (2013) said that these colorful ribbons have the meaning of religious principles in harmony during the ceremony.

Shamanism or paganism has an essential role for Russian culture because it is the identity of the Russian nation that has been attached since ancient times. It is still preserved until now. Therefore, the book "Barthes: A Very Short Introduction," based on the theory of semiotic by Roland Barthes, shows that culture will constantly adapt to the social conditions of the local society (Culler, 2001). The practice of the Taylagan festival has proven that culture is not static and continuously changes. In this case, some changes can be seen in several instruments used during the ritual. That is why semiotic theory is used as an analytical tool to interpret the changing symbols and signs of the Taylagan Festival. According to Hoed (1996), cultural phenomena are seen as "open" signs and meanings are interpreted by people who interpret the signs themselves, which has various interpretations so that Barthes, through the theory of semiotic, interprets the signifier and the signified that are applied by the author in this article. In addition, as time goes by, culture will adapt to society. This also impacts the Taylagan Festival, which brings up a new name for a new generation of shamans, 'Neo-shaman', and their openness to the public about their culture.

\section{Conclusion}

Shamanism goes through ups and downs in Russia: from the Tsar Era, the beginning of the Soviet Union Era that prohibited all kinds of religious events, to a new policy at the end of the Soviet Union Era. They can be able to adapt well to local people in the Contemporary Era in Russia. The arrival of Perestroika strongly encouraged the Buryat Shaman on the Olkhon island, Siberia, to perform their ritual or tradition again. Based on the results of interview analysis, photos by the respondents who have participated in the Taylagan Festival, and several videos by the Russian news programs and using semiotic theory by Roland Barthes and invention of tradition theory by Eric Hobsbawm, it can be seen that Russians in the Contemporary Era still believe in shamans and know the shaman rituals. They know Buryat shaman rituals, such as communicating with spirits to heal people and controlling the weather. Shamanism, all the traditions, and rituals are a cultural phenomenon that has attracted the attention of Russians and foreign tourists.

The changing meaning of the Taylagan Festival has undergone a process of adaption in the Contemporary Era. There were several changes in the Buryat shaman community, such as Neo-Shamans or new shamans in Siberia. The increase in the number of visitors to the Taylagan ritual and the times is also clearly seen from several official Russian media. The rise of shamanism in Russia has positively impacted the Buryat shaman and the Russian people because it can improve the local tourism, economy, and social sectors. Thus, this research's contribution is to fill in the gaps in previous research on the Russian Buryat Shaman and the Taylagan Festival. The subsequent research can discuss other festivals related to the changing meaning of the Buryat shaman in Russia.

\section{Declaration of Ownership}

This article is our original work.

\section{Conflict of Interest}

There is no conflict of interest to declare in this article. 


\section{Ethical Clearance}

This study was approved by the institution.

\section{References}

Balogh, M. (2010). Contemporary shamanism in Mongolia. Asian Ethnicity, 11(2), 229-238. https://doi. org/10.1080/14631361003779489

Balzer, M. M. (2016). Art, identity and ethnicity: Republics of Kalmykia, Buryatia, Altai, and Sakha (Yakutia). Anthropology \& Archeology of Eurasia, 54(3), 1-5. https://doi.org/10.1080/106119 59.2015.1207402

Balzer, M. M. (2008). Beyond belief? Social, political, and shamanic power in Siberia. Social Analysis: The International Journal of Anthropology, 52(1), 95-110.

Bernstein, A. (2008). Remapping sacred landscapes: Shamanic tourism and cultural production on the Olkhon Island. Sibirica, 7(2), 23-46. https://doi. org/10.3167/sib.2008.070203

Bernstein, A. (2011). The Post-Soviet treasure hunt: Time, space, and necropolitics in Siberian Buddhism. Comparative Studies in Society and History, 53(3), 623-653. https:// doi.org/10.1017/S0010417511000272

Blain, J., \& Wallis, R. J. (2006). Ritual reflections, practitioner meanings disputing the terminology of neoshamanic 'performance'. Journal of Ritual Studies, 20(1), 21-36.

Buyandelgeriyn, M. (1999). Who 'makes' the shaman? The Politics of Shamanic Practices among the Buriats Mongolia. Inner Asia, 1(2), 221-224.

Bužeková, T. (2010). The shaman's journeys between emic and etic: Representations of the shaman in neo-shamanism. Anthropological Journal of European, 19(1), 116-130. https://doi.org/10.3167/ ajec.2010.190109
Chilson, C \& Knect, P. (2003). Shamans in Asia. Routledge.

Creswell, J.W. (2007). Qualitative inquiry and research design: Choosing among five approaches (Vol. III). Thousand Oaks.

Culler, J. (2001). Barthes: A very short introduction. Oxford University Press.

Darkhanova, A. I. (2009). Klassifikatsiya sovremennykh buryatskikh shamanov. Archeology and Ethnography, 8(5), 293-299.

Eliade, M. (1964). Shamanism: Archaic techniques of ecstasy. Routledge.

Federal'naya Sluzhba Gosudarstvennoy Statistiki [Федеральная Служба Государственной Статистики]. (2016). Rossiya i Strany Mira [Россия и Страны Mupa]

Gorbatcheva, V., \& Federova, M. (2016). Art of Siberia. Parkstone Press International.

Hamayon, R.N.(1998).Shamanism,Buddhism and epic heroism: Which supports the identity of the post-Soviet Buryats? Central Asian Survey, 17(1), 51-67. https:// doi.org/10.1080/02634939808401023

Hobsbawm, E., \& Ranger, T. (1983). The invention of tradition. Cambridge University Press.

Hoed, B. H. (1996). Linguistik, semiotik, dan kebudayaan kita. Fakultas Sastra Universitas Indonesia.

Hosking, G., \& Service, R. (1998). Russian nationalism past and present. School of Slavonic and East European Studies, University of London.

Humphrey, C. (1999). Shamans in the city. Anthropology Today, 15(3), 3-10.

Hürelbaatar, A. (2000). An introduction to the history and religion of the Buryat Mongols of Shinehen in China. Inner Asia, 2(1), 73-116.

Ivanov, V. V. (2008). Russia between east and west? Remarks on comparison of cultures. Russian Journal of Communication, 1(2), 
113-126. https://doi.org/10.1080/1940941 9.2008.10756705

Jonutytè, K. (2019). Buddhists, Shamans, and Soviets: Rituals of history in post-Soviet Buryatia. Religion, State, \& Society, 48(1), 76-77. https://doi.org/10.1080/09637494.2 020.1705080

Konstitutsiya Rossiyskoy Federatsii [Конституцุия Российской Федерациии]. (2008). Russia.

Krader, L. (1954). Buryat religion and society. Southwestern Journal of Anthropology, 10(3), 322-351.

Krader, L. (1975). The shamanist tradition of the Buryats (Siberia). Anthropos, 70(1), $105-144$.

Krist, S. (2014). Wrestling magic: National wrestling in Buryatia, Mongolia and Tuva in the past and today. The Internation Journal of the History of Sport, 31(4), 423444. https://doi.org/10.1080/09523367.201 3.869214

Li, L. (1992). The symbolization process of the shamanic drums used by the Manchus and other peoples in North Asia. Yearbook for Traditional Music, 24(1), 52-80.

Mitrofanova, A. (2016). The new Russian nationalism: Imperialism, ethnicity and authoritarianism 2000-2015. Edinburgh University Press.

Namsaraeva, S. (2012). Ritual, memory and the Buriad diaspora notion of home. Frontier Encounters, 137-163. https://doi. org/10.11647/obp.0026.08

Paro, L. K. (2011). A methodology for a deconstruction and reconstruction of the concepts of "shaman" and "shamanism". Numen, 28(1), 6-70. https://doi. org/10.1163/156852711x540087

Shevchenko, N. (2019). Baikal's shamans battle spirits, demons and the worst foe of all each other. Russia Beyond. https://www. rbth.com/travel/329944-exorcism-baikalshamans-siberia-russia

Siembieda, K. (1998). Mystic Russia. Palladium Books.

Tagangaeva, M. (2015). Visualising (Post)Soviet ethnicity: Fine art of Buryatia. Anthropology \& Archeology of Eurasia, 54(3), 24-57. https://doi.org/10.1080/1061 1959.2016.1194699

Wierucka, A. (2013). Modern forms of Buryat shaman activity on the Olkhon Island. Anthropological Notebooks, 19(3), 101-119.

Zabelina, V. (2019). Cultural identity in Siberia and in analytical practice. The Society of Analytical Psychology, 64(4), 548-564. https://doi.org/10.1111/14685922.12520

Zhukovskaya, N. L. (1995). Religion and ethnicity in Eastern Russia, Republic of Buryatia: A panorama of the 1990s, Central Asian Survey, 14(1), 25-42. https:// doi.org/10.1080/02634939508400890

Zhukovskaya, N. L., \& Humphrey, C. (2000). Neo-Shamanism in the context of the contemporary ethno-cultural situation in the Republic of Buryatia. Inner Asia, 2(1), 25-26.

Zohrab, I. (1987). Russia and Mongolia. New Zealand Slavonic Journal, 177-203. 